\title{
Arteriovenous Malformations and Other Vascular Malformation Syndromes
}

\author{
Kevin J. Whitehead ${ }^{1,2,3}$, Matthew C.P. Smith ${ }^{1,4}$, and Dean Y. Li ${ }^{1,2,4}$ \\ ${ }^{1}$ Molecular Medicine Program, University of Utah, Salt Lake City, Utah 84112 \\ ${ }^{2}$ Department of Internal Medicine, University of Utah, Salt Lake City, Utah 84112 \\ ${ }^{3}$ Utah Hereditary Hemorrhagic Telangiectasia Center of Excellence, University of Utah, Salt Lake City, \\ Utah 84112 \\ ${ }^{4}$ Department of Oncological Sciences, University of Utah, Salt Lake City, Utah 84112 \\ Correspondence: kevin.whitehead@hsc.utah.edu
}

Vascular malformations are a disruption of the normal vascular pattern in which it is expected that a capillary network of microscopic vessels lies interposed between high-pressure arteries that deliver blood and thin-walled veins that collect low-pressure blood for return to the heart. In the case of arteriovenous malformations, arteries or arterioles connect directly to the venous collection system, bypassing any capillary bed. Clinical consequences result from rupture and hemorrhage, from dramatically increased blood flow, or from the loss of capillary functions such as nutrient exchange and filtering function. These malformations can occur sporadically or as a component of inherited vascular malformation syndromes. In these and other hereditary vascular malformation syndromes, genetic studies have identified proteins and pathways involved in vascular morphogenesis and development. A common theme observed is that vascular malformations result from disruption in pathways involved in vascular stability. Here we review the vascular malformations and pathways involved in hereditary hemorrhagic telangiectasia, capillary malformation-arteriovenous malformation, cerebral cavernous malformations, and mucocutaneous venous malformations.

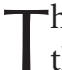

he vertebrate circulatory system depends on the delivery of blood to tissues by arteries and the collection and the return of blood to the heart by veins. In normal circulation, arteries and veins communicate through capillaries, microvascular connections that allow for efficient exchange of nutrients, wastes, oxygen, and carbon dioxide. The control of this system must be dynamic and responsive to changes due to growth, injury, and disease.
The complexities involved in tightly regulating this relationship open up opportunities for misregulation and disturbed vascular morphogenesis resulting in vascular malformations.

\section{ARTERIOVENOUS MALFORMATIONS}

The normal vascular pattern is disrupted in the case of arteriovenous malformations (AVMs), in which an artery or arteriole connects directly to

Editors: Michael Klagsbrun and Patricia D'Amore

Additional Perspectives on Angiogenesis available at www.perspectivesinmedicine.org

Copyright (C) 2013 Cold Spring Harbor Laboratory Press; all rights reserved; doi: 10.1101/cshperspect.a006635

Cite this article as Cold Spring Harb Perspect Med 2012;3:a006635 
K.J. Whitehead et al.

a vein or venule, bypassing nutrient exchange and shunting blood directly to the venous system. Arteriovenous malformations consist of clusters of dilated feeding arteries or arterioles that collect to a nidus, where there is a connection to a draining vein or system of veins (Al-Shahi and Warlow 2001). The lesion is termed an "arteriovenous fistula" if there is a connection between a single dilated artery and vein (Al-Shahi and Warlow 2001). AVMs are encountered in both systemic and pulmonary vascular beds and may be isolated lesions or associated with other clinical syndromes. In some organs and tissues, AVMs pose a significant clinical problem. Brain AVMs are a common cause of intracranial hemorrhage, particularly in younger populations (Al-Shahi and Warlow, 2001). AVMs have been described in almost every tissue or organ (Terry et al. 1980; Ishihara et al. 1997; Al-Shahi and Warlow 2001; Matsushige et al. 2004; Buscarini et al. 2005; Cura et al. 2010) and can lead to significant complications. The etiology of AVMs is not clear. Both congenital and posttraumatic forms have been observed. Although many AVMs are isolated, sporadic findings, they form an important aspect of some vascular malformation syndromes. A review of these syndromes and the underlying genetics has shed some light on mechanisms that can cause AVMs.

\section{AVM: Hereditary Hemorrhagic Telangiectasia}

Hereditary hemorrhagic telangiectasia (HHT) is a rare inherited vascular disorder affecting multiple vascular beds and associated with significant morbidity (Guttmacher et al. 1995; Govani and Shovlin 2009). This syndrome was originally differentiated from hemophilia by Henri Rendu in 1896 (Rendu 1896) and was well described in early case reports by Sir William Osler (Osler 1900) and Frederick Parkes Weber (Weber 1907) in the early 1900s. In recognition of these early descriptions, the condition is sometimes referred to as OslerWeber-Rendu syndrome. HHT is characterized by spontaneous epistaxis, mucocutaneous telangiectasias, and visceral AVMs associated with a family history of the syndrome. These four components constitute the Curaçao diagnostic criteria (Shovlin et al. 2000) for the condition. The presence of three or four of these components is diagnostic of HHT, whereas with one or fewer criteria the diagnosis is unlikely. Patients with HHT almost universally develop telangiectasias of the nasal mucosa and skin, which consist of dilated postcapillary venules with increased smooth muscle investiture often connected directly to dilated arterioles (Guttmacher et al. 1995). The genetic basis for HHT has been investigated, and mutations in any of three genes have been found to be associated with the condition. The majority of cases can be attributed to either endoglin (McAllister et al. 1994) (HHT type 1) or Activin receptorlike kinase 1 (Johnson et al. 1996) (ACVRL1HHT type 2). A minority of cases is associated with mutations in SMAD4 (Gallione et al. 2004), in which there is clinical overlap with juvenile polyposis. All three of these genes are notable for their recognized roles in binding or signaling associated with the transforming growth factor- $\beta$ (TGF- $\beta$ ) family of ligands (Govani and Shovlin 2009). Clinically significant AVMs of the brain, lung, liver, and GI tract are found in a significant minority of HHT patients (Guttmacher et al. 1995; Govani and Shovlin 2009).

The mutations that result in HHT include deletions, insertions, missense, nonsense, and splice-site mutations (Govani and Shovlin 2009) and are generally thought to result in loss of protein function. As more is known about the function of these proteins, mechanisms of AVM pathogenesis are being explored. Endoglin is an endothelial-specific cell surface protein (also known as CD105) that binds TGF- $\beta$ ligands (McAllister et al. 1994) but has no known signaling functions. Matrix or cellsurface localization of these growth factors is a well-recognized mechanism essential for proper signaling, and loss of localizing proteins not only leads to HHT but is felt to be an important mechanism in Marfan syndrome (Neptune et al. 2003) as well. After the ligand is localized to the endothelial cell, signaling of TGF- $\beta$ ligands involves binding to type II receptors (such as ACVRL1), which associate with and 
phosphorylate type I receptors (Govani and Shovlin 2009). Upon phosphorylation, type II receptors become activated and phosphorylate downstream targets including the receptorassociated SMADs (SMADs 1, 2, 3, 5, and 8), which, in turn, bind with SMAD4 and translocate to the nucleus to affect gene transcription (Govani and Shovlin 2009). That the loss of endoglin or ACVRL1 results in a very similar clinical syndrome suggests that both genes lie in a common genetic pathway. Recent studies suggest that the probable ligands for this pathway are the bone morphogenetic proteins (BMPs) 9 and 10 (David et al. 2007; Scharpfenecker et al. 2007). Because heterozygosity for either endoglin or ACVRL1 is associated with HHT, it suggests that the disease results primarily from a decrease in signal from this common HHT pathway, as opposed to a new, pathologic signal from an alternative pathway.

Animal models have been developed to explore the in vivo functions of these proteins. The complete loss of either endoglin or AVCRL1 results in embryonic death in mid-gestation, with profound vascular abnormalities (Bourdeau et al. 1999; Li et al. 1999; Arthur et al. 2000; Oh et al. 2000; Urness et al. 2000). Interestingly, mice lacking either protein develop abnormal arteriovenous connections and shunts between the developing aorta and cardinal vein, and die as a consequence of inefficient circulation due to AVMs (Urness et al. 2000; Sorensen et al. 2003). Unlike humans, mice heterozygous for HHT proteins do not develop epistaxis or AVMs with predictably high penetrance. Indeed, it is common that mice with the same genetic lesion as humans do not share identical phenotypes. Although certain background mouse strains can encourage some features of HHT (Bourdeau et al. 1999), the disease is more profoundly manifested by the induced complete knockout of Acvrll after critical stages of vascular development are allowed to proceed (Park et al. 2009). Using a tamoxifen-responsive Cre recombinase expressed in all tissues, including endothelium of all vascular beds, Park et al. (2009) recently showed the real-time development of AVMs in their mouse conditional mutant for Acvrl1.
Although some vascular beds were prone to spontaneously develop AVMs, telangiectasias and AVMs of the skin only developed as a response to injury. This pattern has some analogy to HHT clinically, because AVMs in HHT patients are observed early and may be congenital in some vascular beds, such as brain, yet telangiectasias develop over time with predisposition for areas subject to trauma (Govani and Shovlin 2009).

\section{AVM: Capillary Malformation-Arteriovenous Malformation}

Recently another hereditary clinical vascular malformation syndrome has been described (Table 1) (Eerola et al. 2003) in which affected patients develop capillary malformations of the skin in a variety of locations, often associated with underlying AVMs or AV fistulae. The underlying high-flow lesions can occasionally alter the appearance of the otherwise erythematous capillary malformations, resulting in a pale halo surrounding the lesion (Boon et al. 2005). Some affected patients have more extensive involvement including hypertrophy and overgrowth of an affected limb (Parkes Weber syndrome). In light of these combined features, the syndrome has been termed CM-AVM. Families with CM-AVM have been found to have mutations in RASA1 encoding p120Ras-GAP (Eerola et al. 2003), a protein that regulates the activity of Ras.

Unlike HHT, in which the underlying mutations suggest abnormal growth factor signaling, the mutations in CM-AVM suggest a problem with signaling from small GTPases. Small GTPases are molecular switches that are well positioned to act as regulators of endothelial cell-cell interactions, junctional proteins, and the cellular cytoskeleton. Ras is a GTPase known to be important in linking signals from receptor tyrosine kinases (RTKs) at the cell surface to mitogen-activated protein kinase (MAPK) pathways in the cell to regulate growth, differentiation, and proliferation (Karnoub and Weinberg 2008). The importance of Ras in vivo is confirmed by the identification of increased levels of activated Ras in cancer cells. Since the 
K.J. Whitehead et al.

Table 1. Genetic vascular malformation syndromes

\begin{tabular}{|c|c|c|c|c|}
\hline Syndrome & $\begin{array}{l}\text { Associated } \\
\text { malformations }\end{array}$ & Gene & Mutations & Phenotype \\
\hline \multirow{3}{*}{$\begin{array}{l}\text { Hereditary } \\
\text { hemorrhagic } \\
\text { telangiectasia } \\
\text { (HHT) }\end{array}$} & \multirow{3}{*}{$\begin{array}{l}\text { Arteriovenous } \\
\text { malformations, } \\
\text { mucocutaneous } \\
\text { telangiectasias }\end{array}$} & $\begin{array}{l}\text { Endoglin (HHT } \\
\text { type 1) }\end{array}$ & Loss of function & $\begin{array}{l}\text { Epistaxis, skin } \\
\text { telangiectasias, lung, } \\
\text { brain, and liver AVMs }\end{array}$ \\
\hline & & $\begin{array}{l}A C V R L 1(\mathrm{HHT} \\
\text { type } 2)\end{array}$ & Loss of function & $\begin{array}{l}\text { Similar to type } 1 \text {, but lung } \\
\text { AVM less common, liver } \\
\text { AVM more common }\end{array}$ \\
\hline & & SMAD4 $(H H T / J P)$ & Loss of function & $\begin{array}{l}\text { Overlap syndrome of } \\
\text { typical HHT plus } \\
\text { juvenile polyposis }\end{array}$ \\
\hline \multirow[t]{3}{*}{$\begin{array}{l}\text { Cerebral cavernous } \\
\text { malformations } \\
(\mathrm{CCMs})\end{array}$} & \multirow{3}{*}{$\begin{array}{l}\text { Cerebral and retinal } \\
\text { cavernous } \\
\text { malformations, } \\
\text { cutaneous } \\
\text { capillary } \\
\text { malformations, } \\
\text { and } \\
\text { hyperkeratotic } \\
\text { cutaneous } \\
\text { capillary venous } \\
\text { malformations }\end{array}$} & KRIT1 (CCM1) & Loss of function & $\begin{array}{l}\text { Multiple brain CCMs, high } \\
\text { disease penetrance by } \\
\text { MRI screening, subset } \\
\text { asymptomatic }\end{array}$ \\
\hline & & CCM2 & Loss of function & Similar to CCM1 \\
\hline & & PDCD10 (CCM3) & Loss of function & $\begin{array}{l}\text { More severe phenotype, } \\
\text { earlier onset, smaller } \\
\text { families }\end{array}$ \\
\hline $\begin{array}{l}\text { Capillary } \\
\text { malformation- } \\
\text { arteriovenous } \\
\text { malformation } \\
\text { (CM-AVM) }\end{array}$ & $\begin{array}{l}\text { Capillary } \\
\text { malformations, } \\
\text { arteriovenous } \\
\text { malformations, } \\
\text { arteriovenous } \\
\text { fistulae, Parkes } \\
\text { Weber syndrome }\end{array}$ & RASA1 & Loss of function & $\begin{array}{l}\text { Capillary malformations, } \\
\text { some with pale "halo" } \\
\text { caused by vascular steal } \\
\text { from underlying high- } \\
\text { flow AVM. Rare family } \\
\text { members have associated } \\
\text { hypertrophy of an } \\
\text { affected limb (Parkes } \\
\text { Weber syndrome). }\end{array}$ \\
\hline $\begin{array}{l}\text { Cutaneomucosal } \\
\text { venous } \\
\text { malformations } \\
\text { (VMCMs) }\end{array}$ & $\begin{array}{l}\text { Multifocal } \\
\text { mucocutaneous } \\
\text { small venous } \\
\text { lesions, other } \\
\text { venous } \\
\text { malformations }\end{array}$ & TEK & $\begin{array}{l}\text { Missense, } \\
\text { activating } \\
\text { mutations }\end{array}$ & $\begin{array}{l}\text { Variability from cosmetic } \\
\text { vascular lesions to } \\
\text { multifocal venous } \\
\text { malformations affecting } \\
\text { vital organs }\end{array}$ \\
\hline
\end{tabular}

identification of Ras, more than 100 further GTPases have been identified and characterized in separate families of the Ras "superfamily" of GTPases based on structural and functional characteristics. The Rho (Ras homolog) family GTPases were originally identified on the basis of homology with Ras and have been shown to control the cellular cytoskeleton and influence cell-cell interactions in several cell types including endothelial cells (Etienne-Manneville and Hall 2002).
These proteins are activated when bound to GTP and then become inactivated as they hydrolyze GTP to GDP. The dynamics of GTP binding and hydrolysis, as well as the subcellular localization of GTPases, contribute to the biologic effects of these systems. A variety of associated proteins modulate GTPase activity by promoting GDP-GTP exchange (guaninenucleotide exchange factors, or GEFs) or by promoting GTP-GDP hydrolysis (GTPaseactivating proteins, or GAPs). Scaffold proteins 
contribute to GTPase regulation by bringing the GTPase switch into proximity with downstream signaling effectors (Jaffe et al. 2005), and posttranslational isoprenylation allows GTPases to localize with membranes correctly. The potential complexity of GTPase signaling is staggering, and in vitro studies cannot confirm the importance of individual pathways in vivo. Human vascular malformation syndromes such as CM-AVM have highlighted GTPase-associated pathways that are of particular importance to vascular morphogenesis and stability in vivo.

The mutations found in CM-AVM result in a loss of function of p120-RasGAP, which is a GTPase-activating protein. Because GTPase activity leads to hydrolysis of GTP to GDP and inactivates signaling, the loss of p120-RasGAP opens the potential for increased Ras activation. RASA1 has homology with neurofibromin (NF1), the gene mutated in cases of neurofibromatosis, yet NF1 expression is not sufficient to compensate for loss of RASA1 in families with CM-AVM (Boon et al. 2005). The importance of RASA1 relative to NF1 or two other homologous genes, RASA2 and RASAL, in vascular stability would not have been predicted on the basis of in vitro studies and was clearly shown by human genetic studies.

In addition to its function as a Ras-GAP, p120-RasGAP has been shown to associate with p190-RhoGAP, where it may influence Rho kinases to modulate the cellular cytoskeleton (Settleman et al. 1992a,b). Furthermore, p120-RasGAP associates with Rapla (Frech et al. 1990), a GTPase often associated with cellular adhesion and cell-cell interactions, and the bait used to initially identify KREV1/RAP1a interaction trapped 1 (KRIT1) (Serebriiskii et al. 1997), a gene subsequently found to be mutated in a subset of families with cerebral cavernous malformations (CCMs) (Laberge-le Couteulx et al. 1999; Sahoo et al. 1999).

\section{Cerebral Cavernous Malformations}

Cerebral cavernous malformations (CCMs) are common vascular malformations described predominantly in the central nervous system. Lesions consist of dilated endothelial channels or caverns lacking smooth muscle support and filled with blood or thrombus (Labauge et al. 2000). Occasionally, CCMs rupture, leading to hemorrhagic stroke or death. Even in the absence of overt hemorrhage, all lesions are associated with hemosiderin, a blood breakdown product in the surrounding brain parenchyma. Ultrastructural studies suggest absent or diminished tight junctions, implying localized loss of the blood-brain barrier (Clatterbuck et al. 2001).

CCM lesions are found with a prevalence of one in 200 people (Otten et al. 1989; Vernooij et al. 2007). Approximately $20 \%$ of patients have familial disease, following an autosomaldominant pattern of inheritance. CCM has been linked to loss-of-function mutations in the genes encoding any of three structurally distinct proteins-KRIT1 (CCM1) (Laberge-le Couteulx et al. 1999; Sahoo et al. 1999), CCM2 (Osmosensing Scaffold for MEKK3, OSM; Malcavernin; or MGC4607) (Liquori et al. 2003; Denier et al. 2004), or Programmed cell death 10 (PDCD10; CCM3) (Bergametti et al. 2005). For a more complete review of CCM genetics, see Riant et al. (2009). The three CCM disease genes are structurally unrelated intracellular proteins that lack catalytic domains and have been found to associate with one another, and influence a variety of signaling pathways. This topic was recently reviewed in greater detail by Faurobert (Faurobert and Albiges-Rizo 2009).

Initial evidence that CCM might result from abnormal GTPase activity came with the identification of KRIT1 mutations in families with CCM and linkage to CCM1. Further proof that the KRIT1-RAP1a interaction is functionally important came from studies in endothelial cells in vitro (Glading et al. 2007) and Krit1 heterozygous knockout mice in vivo (Glading and Ginsberg 2010). KRIT1 and RAP1a interact to influence endothelial cell junctional integrity through downstream signaling cascades such as $\beta$-catenin signaling. Krit1 has also been shown to interact genetically with the related GTPase, Rap1b (Gore et al. 2008).

CCM2 was identified simultaneously as a gene associated with familial CCM and as a scaffold protein to facilitate stress signaling from the 
small GTPase Rac1 to p38 MAPK (Uhlik et al. 2003). CCM2 also associates with RhoA, and the loss of CCM2 leads to increased RhoA activity in the endothelium (Whitehead et al. 2009). Increased RhoA activity is associated with vascular instability, and favorable effects of RhoA inhibition in CCM2 deficiency are seen both in vitro and in vivo, suggesting a possible therapeutic strategy for CCM disease (Whitehead et al. 2009). A similar mechanism appears to be present in KRIT1 deficiency (Stockton et al. 2010).

Until recently little was known about PDCD10. This gene was initially identified in a screen for proteins associated with apoptosis. As with KRIT1 and OSM, until the protein was linked to CCM disease, there was little to suggest the importance of this gene in the vasculature by structure, homology, or expression pattern (Petit et al. 2006). Overexpression studies have found that PDCD10 can be found in association with KRIT1 and OSM (Hilder et al. 2007), suggesting a possible common mechanism. Increased RhoA activity has also been observed with the loss of PDCD10 (Zheng et al. 2010). However, rather than binding to GTPases and MAPKs, PDCD10 has been found to associate with serine-threonine kinases (STKs), including STK24, STK25, and MST4, and a further complex of associated proteins (Goudreault et al. 2009). Whether this complex represents a unique, PDCD10-associated signaling mechanism, or whether with endogenous levels of protein there is cross talk between PDCD10 and KRIT1, OSM and GTPase pathways is not known. The loss of any of these three proteins results in a common vascular pathology, yet it is not clear whether CCM represents the end stage of a single pathogenic process or an unexpectedly common result of distinctly different (genotype-specific) pathways.

The GTPase pathways associated with CMAVM and CCM regulate vascular permeability and control endothelial cell-cell interactions. With this observation, a theme is introduced that the loss of proteins that regulate vascular stability results in vascular malformations. This is particularly well illustrated in the case of cutaneomucosal venous malformations.

\section{Cutaneomucosal Venous Malformations (VMCMs)}

Venous malformations (VMs) are the most common of vascular malformations and account for $>50 \%$ of individuals reporting to vascular malformation centers. VMs are the result of local aberrations in angiogenesis occurring in fetal development and can range in clinical spectrum from benign cosmetic varicosities to multifocal lesions in multiple vital organs (Brouillard and Vikkula 2003; Wouters et al. 2009). The majority of vascular malformations have no known genetic component and are sporadic in nature. However, families with dominant inheritance of VMs have been identified, and linkage analysis has localized mutations in the TEK gene on chromosome 9p21. This gene codes for the angiopoietin-1 receptor protein Tie2, and the majority of mutations identified thus far have been in or near the amino-terminal-most of two kinase domains within the intracellular portion of the protein (Wouters et al. 2009). These autosomal-dominant venous malformations termed cutaneomucosal venous malformations (VMCMs) tend to involve small multifocal mucocutaneous lesions in addition to the possibility of other venous malformations. Although they only make up $\sim 2 \%$ of reported venous malformations, the understanding of the genetic factors leading to VMCMs have led to partial understanding of the much more common sporadic venous malformations (Limaye et al. 2009a).

To date, 17 families have been reported with mutations in or near the kinase domain of Tie2, and roughly $60 \%$ of these are missense mutations causing an arginine-tryptophan substitution (R849W) (Limaye et al. 2009b). When exogenously expressed in human umbilical vein endothelial cells (HUVECs), this mutation had no effect on migration or cell proliferation when compared with its wild-type counterpart. However, Tie2-R849W-expressing cells were significantly more resistant to apoptosis by serum withdrawal and formed unstable tubes (Hu et al. 2008), suggesting a possible mechanism for the propagation of vascular malformations that possess a paucity of smooth muscle or 
pericyte support that would normally induce endothelial apoptosis (Benjamin et al. 1999). Additionally, Hu et al. (2008) determined that Tie2-R849W was hyper-autophosphorylated and, unlike its wild-type counterpart, activated the signal transducer and activator of transcription 1 (STAT1) transcription factor in an Ang1-independent but Janus kinase (JAK)-dependent manner. Intriguingly, however, STAT1 activation has actually been shown to down-regulate angiogenesis in vivo (Battle et al. 2006), suggesting that further evaluation of STAT1 signaling in VMCM patients is warranted and this pathway could be a potential therapeutic target in treating vascular malformations.

Another insight into the understanding of venous malformations has come from the discovery of a "second hit" within the VMCM of an individual with the inherited R849W mutation (Limaye et al. 2009b). Under the hypothesis of a paradominant mode of inheritance for VMCM, they found a Tie2 deletion mutation in the vascular lesion of a single patient that did not correspond to the genotype of DNA isolated from the blood of this patient. This finding prompted the investigators to sequence DNA from vascular malformations of other patients whose VMs were inconsistent with the dominant inherited VMCM. In screening $62 \mathrm{VMs}$ from 57 patients for mutations in TEK (Tie2), the investigators found 30 mutations in 28 individuals. Upon further characterization of the most prominent of these mutations, a leucine-phenylalanine substitution (L914F) within the same kinase domain as the inherited R849W mutation, they determined that this mutation also conferred hyper-autophosphorylation of the Tie2 receptor, suggesting a similar mechanism for the development of sporadic VMs as to that of VMCMs (Limaye et al. 2009b).

\section{CONCLUDING REMARKS}

The vascular system is remarkably well regulated: able to remain stable in established tissues, yet immediately responsive and able to sprout and migrate to perfuse new tissues that form in response to injury or growth. Vascular morphogenesis is normally well controlled, and vascular malformations are fortunately rare. The important role of pro-angiogenic factors such as VEGFs and FGFs in vascular biology has long been appreciated. Vascular malformation syndromes as discussed in this article highlight an underappreciated mechanism in the control of vascular biology - that of stabilizing factors that counteract pro-angiogenic signals. That such mechanisms exist is not surprising. It is a recurring theme in nature that opposing signals are involved in regulating biologic processes, and the balance between opposing forces determines the net effect. Just as the parasympathetic nervous system is the ying to the sympathetic nervous system yang, or that pro-thrombotic pathways are generally held in check by anti-thrombotic mechanisms, thus do pathways of vascular stability predominate in a stable vessel to prevent pathologic vascular leak and excessive angiogenesis and neovascularization. As more stabilizing pathways are appreciated and described, the key proteins involved become candidate genes for these and other vascular malformation syndromes. Similarly, there is a strong possibility that genes associated with vascular malformations are involved in regulating vascular stability.

\section{ACKNOWLEDGMENTS}

This work was funded by grants from the National Institutes of Health: T-32 Hematology training grant (to M.C.P.S.), NHLBI (to D.Y.L and K.J.W.); American Heart Association (to K.J.W. and D.Y.L.); and the Juvenile Diabetes Research Foundation, HA and Edna Benning Foundation, and the Burroughs Wellcome Foundation (to D.Y.L.).

\section{REFERENCES}

Al-Shahi R, Warlow C. 2001. A systematic review of the frequency and prognosis of arteriovenous malformations of the brain in adults. Brain 124: 1900-1926.

Arthur HM, Ure J, Smith AJ, Renforth G, Wilson DI, Torsney E, Charlton R, Parums DV, Jowett T, Marchuk DA, et al. 2000. Endoglin, an ancillary TGF $\beta$ receptor, is required for extraembryonic angiogenesis and plays a key role in heart development. Dev Biol 217: 42-53.

Battle TE, Lynch RA, Frank DA. 2006. Signal transducer and activator of transcription 1 activation in endothelial cells 
K.J. Whitehead et al.

is a negative regulator of angiogenesis. Cancer Res 66: 3649-3657.

Benjamin LE, Golijanin D, Itin A, Pode D, Keshet E. 1999. Selective ablation of immature blood vessels in established human tumors follows vascular endothelial growth factor withdrawal. J Clin Invest 103: 159-165.

Bergametti F, Denier C, Labauge P, Arnoult M, Boetto S, Clanet M, Coubes P, Echenne B, Ibrahim R, Irthum B, et al. 2005. Mutations within the programmed cell death 10 gene cause cerebral cavernous malformations. Am J Hum Genet 76: 42-51.

Boon LM, Mulliken JB, Vikkula M. 2005. RASA1: Variable phenotype with capillary and arteriovenous malformations. Curr Opin Genet Dev 15: 265-269.

Bourdeau A, Dumont DJ, Letarte M. 1999. A murine model of hereditary hemorrhagic telangiectasia. J Clin Invest 104: $1343-1351$

Brouillard P, Vikkula M. 2003. Vascular malformations: Localized defects in vascular morphogenesis. Clin Genet 63: $340-351$.

Buscarini E, Danesino C, Olivieri C, Lupinacci G, Zambell A. 2005. Liver involvement in hereditary haemorrhagic telangiectasia or Rendu-Osler-Weber disease. Dig Liver Dis 37: 635-645.

Clatterbuck RE, Eberhart CG, Crain BJ, Rigamonti D. 2001. Ultrastructural and immunocytochemical evidence that an incompetent blood-brain barrier is related to the pathophysiology of cavernous malformations. J Neurol Neurosurg Psychiatry 71: 188-192.

Cura M, Elmerhi F, Suri R, Bugnone A, Dalsaso T. 2010. Vascular malformations and arteriovenous fistulas of the kidney. Acta Radiol 51: 144-149.

David L, Mallet C, Mazerbourg S, Feige JJ, Bailly S. 2007. Identification of BMP9 and BMP10 as functional activators of the orphan activin receptor-like kinase 1 (ALK1) in endothelial cells. Blood 109: 1953-1961.

Denier C, Goutagny S, Labauge P, Krivosic V, Arnoult M, Cousin A, Benabid AL, Comoy J, Frerebeau P, Gilbert B, et al. 2004. Mutations within the MGC4607 gene cause cerebral cavernous malformations. Am J Hum Genet 74: 326-337.

Eerola I, Boon LM, Mulliken JB, Burrows PE, Dompmartin A, Watanabe S, Vanwijck R, Vikkula M. 2003. Capillary malformation-arteriovenous malformation, a new clinical and genetic disorder caused by RASA1 mutations. Am J Hum Genet 73: 1240-1249.

Etienne-Manneville S, Hall A. 2002. Rho GTPases in cell biology. Nature 420: 629-635.

Faurobert E, Albiges-Rizo C. 2009. Recent insights into cerebral cavernous malformations: A complex jigsaw puzzle under construction. FEBS J 277: 1084-1096.

Frech M, John J, Pizon V, Chardin P, Tavitian A, Clark R, McCormick F, Wittinghofer A. 1990. Inhibition of GTPase activating protein stimulation of Ras-p21 GTPase by the Krev-1 gene product. Science 249: 169-171.

Gallione CJ, Repetto GM, Legius E, Rustgi AK, Schelley SL, Tejpar S, Mitchell G, Drouin E, Westermann CJ, Marchuk DA. 2004. A combined syndrome of juvenile polyposis and hereditary haemorrhagic telangiectasia associated with mutations in MADH4 (SMAD4). Lancet 363: $852-859$.
Glading AJ, Ginsberg MH. 2010. Rap1 and its effector KRIT1/CCM1 regulate $\beta$-catenin signaling. Dis Model Mech 3: 73-83.

Glading A, Han J, Stockton RA, Ginsberg MH. 2007. KRIT-1/CCM1 is a Rap1 effector that regulates endothelial cell cell junctions. J Cell Biol 179: 247-254.

Gore AV, Lampugnani MG, Dye L, Dejana E, Weinstein BM. 2008. Combinatorial interaction between CCM pathway genes precipitates hemorrhagic stroke. Dis Model Mech 1: 275-281.

Goudreault M, D’Ambrosio LM, Kean MJ, Mullin MJ, Larsen BG, Sanchez A, Chaudhry S, Chen GI, Sicheri F, Nesvizhskii AI, et al. 2009. A PP2A phosphatase high density interaction network identifies a novel striatininteracting phosphatase and kinase complex linked to the cerebral cavernous malformation 3 (CCM3) protein. Mol Cell Proteomics 8: 157-171.

Govani FS, Shovlin CL. 2009. Hereditary haemorrhagic telangiectasia: A clinical and scientific review. Eur J Hum Genet 17: 860-871.

Guttmacher AE, Marchuk DA, White RI Jr. 1995. Hereditary hemorrhagic telangiectasia. N Engl J Med 333: 918-924.

Hilder TL, Malone MH, Bencharit S, Colicelli J, Haystead TA, Johnson GL, Wu CC. 2007. Proteomic identification of the cerebral cavernous malformation signaling complex. J Proteome Res 6: 4343-4355.

Hu HT, Huang YH, Chang YA, Lee CK, Jiang MJ, Wu LW. 2008. Tie2-R849W mutant in venous malformations chronically activates a functional STAT1 to modulate gene expression. J Invest Dermatol 128: 2325-2333.

Ishihara T, Hirooka M, Ono T. 1997. Arteriovenous malformation in the buttock: Treatment with a combination of selective embolization and excision. J Dermatol 24: 787-792.

Jaffe AB, Hall A, Schmidt A. 2005. Association of CNK1 with Rho guanine nucleotide exchange factors controls signaling specificity downstream of Rho. Curr Biol 15: 405-412.

Johnson DW, Berg JN, Baldwin MA, Gallione CJ, Marondel I, Yoon SJ, Stenzel TT, Speer M, Pericak-Vance MA, Diamond A, et al. 1996. Mutations in the activin receptor-like kinase 1 gene in hereditary haemorrhagic telangiectasia type 2. Nat Genet 13: 189-195.

Karnoub AE, Weinberg RA. 2008. Ras oncogenes: Split personalities. Nat Rev Mol Cell Biol 9: 517-531.

Labauge P, Brunereau L, Levy C, Laberge S, Houtteville JP. 2000. The natural history of familial cerebral cavernomas: A retrospective MRI study of 40 patients. Neuroradiology 42: 327-332.

Laberge-le Couteulx S, Jung HH, Labauge P, Houtteville JP, Lescoat C, Cecillon M, Marechal E, Joutel A, Bach JF, Tournier-Lasserve E. 1999. Truncating mutations in CCM1, encoding KRIT1, cause hereditary cavernous angiomas. Nat Genet 23: 189-193.

Li DY, Sorensen LK, Brooke BS, Urness LD, Davis EC, Taylor DG, Boak BB, Wendel DP. 1999. Defective angiogenesis in mice lacking endoglin. Science 284: 1534-1537.

Limaye N, Boon LM, Vikkula M. 2009a. From germline towards somatic mutations in the pathophysiology of vascular anomalies. Hum Mol Genet 18: R65-R74. 
Limaye N, Wouters V, Uebelhoer M, Tuominen M, Wirkkala R, Mulliken JB, Eklund L, Boon LM, Vikkula M. 2009b. Somatic mutations in angiopoietin receptor gene TEK cause solitary and multiple sporadic venous malformations. Nat Genet 41: 118-124.

Liquori CL, Berg MJ, Siegel AM, Huang E, Zawistowski JS, Stoffer T, Verlaan D, Balogun F, Hughes L, Leedom TP, et al. 2003. Mutations in a gene encoding a novel protein containing a phosphotyrosine-binding domain cause type 2 cerebral cavernous malformations. Am J Hum Genet 73: 1459-1464.

Matsushige T, Kiya K, Satoh H, Mizoue T, Kagawa K, Araki H. 2004. Arteriovenous malformation of the scalp: Case report and review of the literature. Surg Neurol 62: 253-259.

McAllister KA, Grogg KM, Johnson DW, Gallione CJ, Baldwin MA, Jackson CE, Helmbold EA, Markel DS, McKinnon WC, Murrell J, et al. 1994. Endoglin, a TGF- $\beta$ binding protein of endothelial cells, is the gene for hereditary haemorrhagic telangiectasia type 1. Nat Genet 8: $345-351$.

Neptune ER, Frischmeyer PA, Arking DE, Myers L, Bunton TE, Gayraud B, Ramirez F, Sakai LY, Dietz HC. 2003. Dysregulation of TGF- $\beta$ activation contributes to pathogenesis in Marfan syndrome. Nat Genet 33: 407-411.

Oh SP, Seki T, Goss KA, Imamura T, Yi Y, Donahoe PK, Li L, Miyazono K, ten Dijke P, Kim S, et al. 2000. Activin receptor-like kinase 1 modulates transforming growth factor- $\beta 1$ signaling in the regulation of angiogenesis. Proc Natl Acad Sci 97: 2626-2631.

Osler W. 1900. On a family form of recurring epistaxis associated with multiple telangiectases of the skin and mucous membranes. Bull Johns Hopkins Hosp 12: 333-337.

Otten P, Pizzolato GP, Rilliet B, Berney J. 1989. A propos de 131 cas d'angiomes caverneux (cavernomes) du S.N.C. repérés par l'analyse rétrospective de 24535 autopsies. Neurochirurgie 35: 82-83, 128-131.

Park SO, Wankhede M, Lee YJ, Choi EJ, Fliess N, Choe SW, Oh SH, Walter G, Raizada MK, Sorg BS, et al. 2009. Realtime imaging of de novo arteriovenous malformation in a mouse model of hereditary hemorrhagic telangiectasia. $J$ Clin Invest 119: 3487-3496.

Petit N, Blecon A, Denier C, Tournier-Lasserve E. 2006. Patterns of expression of the three cerebral cavernous malformation (CCM) genes during embryonic and postnatal brain development. Gene Expr Patterns 6: 495-503.

Rendu H. 1896. Épistaxis répétées chez un sujet porteur de petits angiomes cutanés et muqueux. Bull Mem Soc Med Hop Paris 13: 731-733.

Riant F, Bergametti F, Ayrignac X, Boulday G, TournierLasserve E. 2009. Recent insights into cerebral cavernous malformations: The molecular genetics of CCM. FEBS J 277: 1070-1075.

Sahoo T, Johnson EW, Thomas JW, Kuehl PM, Jones TL, Dokken CG, Touchman JW, Gallione CJ, Lee-Lin SQ, Kosofsky B, et al. 1999. Mutations in the gene encoding KRIT1, a Krev-1/rapla binding protein, cause cerebral cavernous malformations (CCM1). Hum Mol Genet 8: 2325-2333.

Scharpfenecker M, van Dinther M, Liu Z, van Bezooijen RL, Zhao Q, Pukac L, Lowik CW, ten Dijke P. 2007. BMP-9 signals via ALK1 and inhibits bFGF-induced endothelial cell proliferation and VEGF-stimulated angiogenesis. $J$ Cell Sci 120: 964-972.

Serebriiskii I, Estojak J, Sonoda G, Testa JR, Golemis EA. 1997. Association of Krev-1/rapla with Kritl, a novel ankyrin repeat-containing protein encoded by a gene mapping to 7q21-22. Oncogene 15: 1043-1049.

Settleman J, Albright CF, Foster LC, Weinberg RA. 1992a. Association between GTPase activators for Rho and Ras families. Nature 359: 153-154.

Settleman J, Narasimhan V, Foster LC, Weinberg RA. 1992b. Molecular cloning of cDNAs encoding the GAP-associated protein pp190: Implications for a signaling pathway from ras to the nucleus. Cell 69: 539-549.

Shovlin CL, Guttmacher AE, Buscarini E, Faughnan ME, Hyland RH, Westermann CJ, Kjeldsen AD, Plauchu H. 2000. Diagnostic criteria for hereditary hemorrhagic telangiectasia (Rendu-Osler-Weber syndrome). Am J Med Genet 91: 66-67.

Sorensen LK, Brooke BS, Li DY, Urness LD. 2003. Loss of distinct arterial and venous boundaries in mice lacking endoglin, a vascular-specific TGF $\beta$ coreceptor. Dev Biol 261: $235-250$.

Stockton RA, Shenkar R, Awad IA, Ginsberg MH. 2010. Cerebral cavernous malformations proteins inhibit Rho kinase to stabilize vascular integrity. $J$ Exp Med 207: 881-896.

Terry PB, Barth KH, Kaufman SL, White RI Jr. 1980. Balloon embolization for treatment of pulmonary arteriovenous fistulas. N Engl J Med 302: 1189-1190.

Uhlik MT, Abell AN, Johnson NL, Sun W, Cuevas BD, LobelRice KE, Horne EA, Dell'Acqua ML, Johnson GL. 2003. Rac-MEKK3-MKK3 scaffolding for pp38 MAPK activation during hyperosmotic shock. Nat Cell Biol 5: 1104-1110.

Urness LD, Sorensen LK, Li DY. 2000. Arteriovenous malformations in mice lacking activin receptor-like kinase-1. Nat Genet 26: 328-331.

Vernooij MW, Ikram MA, Tanghe HL, Vincent AJ, Hofman A, Krestin GP, Niessen WJ, Breteler MM, van der Lugt A. 2007. Incidental findings on brain MRI in the general population. N Engl J Med 357: 1821-1828.

Weber FP. 1907. Multiple hereditary developmental angiomata (telangiectases) of the skin and mucous membranes associated with recurring haemorrhages. Lancet 2: $160-162$.

Whitehead KJ, Chan AC, Navankasattusas S, Koh W, London NR, Ling J, Mayo AH, Drakos SG, Marchuk DA, Davis GE, et al. 2009. The cerebral cavernous malformation signaling pathway promotes vascular integrity via Rho GTPases. Nat Med 15: 177-184.

Wouters V, Limaye N, Uebelhoer M, Irrthum A, Boon LM, Mulliken JB, Enjolras O, Baselga E, Berg J, Dompmartin A, et al. 2009. Hereditary cutaneomucosal venous malformations are caused by TIE2 mutations with widely variable hyper-phosphorylating effects. Eur J Hum Genet 18: $414-420$.

Zheng X, Xu C, Di Lorenzo A, Kleaveland B, Zou Z, Seiler C, Chen M, Cheng L, Xiao J, He J, et al. 2010. CCM3 signaling through sterile 20 -like kinases plays an essential role during zebrafish cardiovascular development and cerebral cavernous malformations. J Clin Invest 120: 2795-2804. 


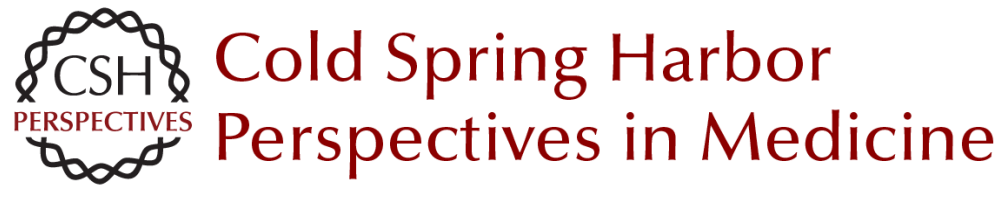

\section{Arteriovenous Malformations and Other Vascular Malformation Syndromes}

Kevin J. Whitehead, Matthew C.P. Smith and Dean Y. Li

Cold Spring Harb Perspect Med 2013; doi: 10.1101/cshperspect.a006635 originally published online November 1, 2012

Subject Collection Angiogenesis

Extracellular Matrix Regulation of Vascular Morphogenesis, Maturation, and Stabilization George E. Davis and Scott S. Kemp

Endothelial Cell-Pericyte Interactions in the

Pathogenesis of Cerebral Cavernous

Malformations (CCMs)

Wang Min and Jenny Huanjiao Zhou

Lymphatic Clearance and Pump Function Jerome W. Breslin

Platelets and (Lymph)angiogenesis Harvey G. Roweth and Elisabeth M. Battinelli

Modeling Brain Vasculature Immune Interactions In Vitro

Ruth Lyck, Hideaki Nishihara, Sidar Aydin, et al.

Human Endothelial Colony-Forming Cells Juan M. Melero-Martin

The Beauty and Complexity of Blood Vessel Patterning

Victoria L. Bautch and Yoh-suke Mukouyama

Endothelialitis, Microischemia, and

Intussusceptive Angiogenesis in COVID-19

Steven J. Mentzer, Maximilian Ackermann and

Danny Jonigk
Regulation of the Blood-Brain Barrier in Health and Disease

Cara C. Rada, Kanako Yuki, Jie Ding, et al.

Targeting Angiogenesis via Resolution of Inflammation

Abigail G. Kelly and Dipak Panigrahy

Notch Signaling in the Vasculature: Angiogenesis and Angiocrine Functions

Sana S. Hasan and Andreas Fischer

Signal Transduction and Gene Regulation in the

Endothelium

Michel V. Levesque and Timothy Hla

Buttons and Zippers: Endothelial Junctions in

Lymphatic Vessels

Peter Baluk and Donald M. McDonald

Endothelial Cell Fate Determination: A Top Notch Job in Vascular Decision-Making

L.A. Naiche, Stephanie R. Villa and Jan K. Kitajewski

Leukocyte Trafficking in Lymphatic Vessels Aline Bauer, Hazal Tatliadim and Cornelia Halin

Lymphatic Tissue and Organ Engineering for In Vitro Modeling and In Vivo Regeneration Anna M. Kolarzyk, Gigi Wong and Esak Lee

For additional articles in this collection, see http://perspectivesinmedicine.cshlp.org/cgi/collection/ 